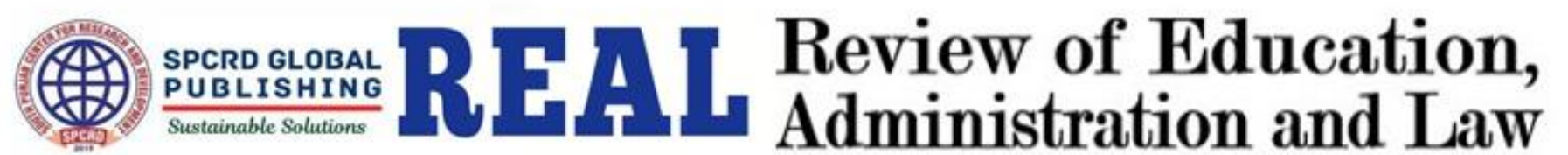 \\ Journal homepage: http://real.spcrd.org ISSN (Print): 2708-1788 ISSN (Online): 2708-3667
}

\section{Comparative Analysis of Education Policy Reforms of Khyber Pakhtunkhuwa (KP) Pakistan since 2008-18}

\author{
${ }^{a}$ Shakeel Khan, ${ }^{b}$ Muhammad Hashim Khan, ${ }^{c}$ Dur-e-Nayab Gul \\ ${ }^{a}$ Lecturer Institute of Management Studies, University of Peshawar, Pakistan \\ Email: shakeel.ims@uop.edu.pk \\ ${ }^{\mathrm{b}}$ Lecturer Institute of Management Studies, University of Peshawar, Pakistan \\ Email: hashim@uop.edu.pk \\ ${ }^{c}$ Lecturer Institute of Management Studies, University of Peshawar, Pakistan \\ Email: nayab.adeel@uop.edu.pk
}

\begin{tabular}{ll}
\hline ARTICLE DETAILS & ABSTRACT \\
\hline History: & The aim of this study is to compare the educational reforms of two \\
Accepted o5 August 2020 & governments in public sector schools within the Khyber Pakhtunkhwa \\
Available Online 30 Sep 2020 & (KPK) region and finds the difference in educational reforms between the \\
& government elected in 2008 and government elected in 2013 in KPK. The \\
& study uses quantitative approach and used secondary data which is \\
Keywords: & collected from the Annual statistical Report issued from 20o9 to 2015. \\
Policy, Education, Reforms, & This research explains relationship between independent variables and \\
Planning, Management & dependent variable through linear and multiple regression technique. \\
& The analysis shows that three independent variables namely Basic \\
JEL Classification: & facilities, Number of teachers, Number of institution has great impact on \\
J48, I21, P11 & student's enrollment which shows changes made by present government \\
& in the education policy has increased the student's enrollment in public \\
& sector schools. The study focuses only on three independent variables \\
while there are some other factors which can affect the student's & enrollment in public sector school.
\end{tabular}

(C) 2020 The authors. Published by SPCRD Global Publishing. This is an open access article under the Creative Commons AttributionNonCommercial 4.0

Corresponding author's email address: shakeel.ims@uop.edu.pk

\section{Introduction}

"There is no doubt that the future of our State will and must greatly depend upon the type of education we give to our children and the way in which we bring them up as future citizens of Pakistan."(M. Ali Jinnah). Despite of such importance of education in Pakistan since its inception, around 25 million children in Pakistan are out of school in their school going age. The condition of education in Pakistan is far away than satisfactory. Education figures of Pakistan have shown that girls 
are the most affected group of the poor or unsatisfactory education system. Number of enrolment of girls in schools is very less in comparison with boys and this disparity increases as one move toward higher levels of education.

According to a study of World Bank, one percent of students in Pakistan leave public schools for Madrassahs because of basic facilities they provide. Condition of public schools in Pakistan is worse in terms of education quality and basic facilities. Public schools have found to have less number of teachers, poor school facilities i.e. classroom furniture, toilets, drinking water and playground etc. In this alarming situation when government spends most of its budget on defense, education reforms needs to be its first priority. Many public schools have been closed in Pakistan due to low enrolment, resulting in decreasing the number of overall institutions.

Khyber Pakhtunkhwa is among the important provinces of Pakistan, it can improve the overall condition of education in Pakistan through effective educational reforms. Condition of public schools is not very much better than public schools in other provinces and reports huge gender disparity in schools. Like other provincial governments in Pakistan, provincial governments in KPK have also introduced several educational reforms whose outcomes were questionable. Recent government of KPK has taken more initiative and stressed on improving public education system and brings parity between the education institutions in KPK than any other government in KPK. Their emphasis on the educational improvement is clear from their huge investment or funds allocation i.e. Rs 136billion in 2018 in comparison with the previous government's Rs 63 billion in 2012-2013.

This study is aimed to make a comparison between the two governments performance with respect to their education policies in KPK. The two governments specifically are the governments resulting from the elections of 2008 and 2013. Comparison is made between the governments in order to understand the outcomes of the huge educational investment of the 2013's elected government in KPK. The study specifically focuses on the public sector girls schools with middle level education, the area which was observed to be badly affected by many authors previously.

The study compares the two governments on the basis of student enrolment, number of teachers, basic facilities in schools and number of institutions/schools. All these variables are considered as the most promising improvement areas for public sector education system in KPK and overall Pakistan. After a comparison the study aims to find out the factors responsible for improvement if any, for that the research uses same variables which were used in the comparison i.e. student enrolment as s dependent variable and basic facilities, number of teachers and number of institutions being independent variables. This research makes use of a Regression analysis technique to find the relationship between each independent variable with the dependent individually and collectively both.

The findings of the research can contribute to the improvement of education system of KPK and Pakistan by highlighting the areas for investment and improvement for the education sector.

\section{Literature Review}

Institutional policy analysis deals with government policy reforms and their impacts or outcomes (William T. Gormley, 1987). From Last several years, educational reforms have become center of attention around the globe (Levin, 1998). Education produces skilled manpower by increasing productivity and efficiency of individuals, resulting in human capital formation capable of moving the economy towards sustainable development. (Gulam Rasool Memon, 2007) 
A cross-country research depicts the importance of women education by revealing that women education has more impact on children schooling than men (Filmer 2000). Furthermore, more equal education between men and women can depict an increase of one percent annual per capita in GDP (klasen 1999). World Bank's 100 country survey reveals that with more no of girls in secondary education can increase annual per capita income up to 0.3 percent. (Dollar \& Ghatti, 1999). In Pakistan, completion rate in primary schools for boys is higher than the girls i.e. three times more than girls in rural areas and two times higher in urban areas (Government of Pakistan, 1997). UNESCO figures (Dawn, 23 Feb 2004, editorial), reveals a great difference between the girls and boys enrolment in Pakistan, with boys having more enrolment than girls.

Pakistan Education statistics report revealed high level of gender inequality in KPK, showing that half of the girls are out of school. Furthermore the report shows that there are more primary schools than secondary and higher secondary schools KPK. The report shows significant improvement in the enrolment number of students in KPK at high school level and mention the provincial government efforts made for improvement of the education system in KPK (Ashfaq, 2018).

The educational institution is supposed to be functional in order to deliver the education to the students in a region therefore it plays very important role on student enrollment. The function of education provide a way to develop the society (Brown et al., 2005; Duru Bellat, 2008) with the help of decorating the knowledge which increase competence ,education increases opportunities for each and every individuals due there is no wastage of talent. Some scholar says that institutes of educations that are functional plays an active role and maintains the hierarchical system in a society (Bourdieu and Passeron, 1977; Yosso, 2002).

School makes it ensure that every individual should take basic knowledge and become competent which is necessary for becoming a part of society (Parsons, 1959; Forquin, 1992 ; Dubet ,2004). It is the suggestion of some scholars that institution of education convert the inequalities of society into inequalities which produces scholars who are different from each other on the basis of their knowledge (Bourdieu and Passeron, 1977; Yosso, 2002). Many educational institutions treat different students differently on the basis of their background.

Shah and Khan (2013) examined the relationship between basic school facilities (such as seats, fans, lights, A.v aids, toilets, water facilities, PC labs, reading room, books and providing the necessary facilities for health and education etc.) and students enrollment. The main aim of this paper is to ensure the quality education in KPK. According to the findings, it is clear that the main problem is that of physical infrastructure, as infrastructure has a direct impact on student's enrollment, learners as well as teachers performance.

Glewwe et al. (2011) said that in developing countries school facilities have significant impact on education outcomes and school enrollment, as they serve as places of learning for children. Results indicated that having a fully functional school (one which contains all the necessary basic facilities) appears beneficial for student learning and also for increasing the number of students enrolled. Neilson \& Zimmerman (2011) provides evidence on the impact of school construction projects on public school enrollment. Positive relationship was founded between school construction and public school enrollment.

Hayat (2017) argued that Pakistani public school system has a lower enrollment rate than other developing countries. Different programs are started for providing basic facilities and for improving 
school infrastructure to increase enrollment. The study indicated that the availability of basic facilities is positively and significantly associated with enrollment. This relationship is stronger for schools in rural areas, for female-only schools and for secondary schools.

According to the report which is based on the changes brought by the present government, it is clear that the KPK government is spending a large amount i.e. Rs. 30 billion approximately on improvement of the condition of current schools and on the construction projects of new schools. This includes the provision of basic facilities including water facilities, electricity, toilets, building and number of classrooms etc. The report says that in terms of provision of basic facilities, KPK is on the top. According to this report, KPK government is still taking actions to improve and establish other facilities which includes playgrounds, well equipped science labs, IT and computer facilities etc. (Ashfaq, 2018)

Impact of schools and teachers on students cannot be denied. A lot of studies by researchers and others have been made which shows influence of institutions and teachers on students. Many of the researchers find out that student own and his/her family background effects the student's admission decisions and scores they obtained. Impact of many different factors which act as inputs like experience of teachers, number of teachers, degree level of teachers, spending per student appears to be less important in forecasting the results; the effect of particularly one factor does not remain same through studies. (Hanushek 1986).

Among all factors which are important and effect the student enrollment, number of teachers in schools is an important one. Teachers were available in the schools but many teachers which are present not take their classes properly and on time. Many countries which are not developed including our country Pakistan, this system of education is divided into two branches which are c formalized and centralized government. At 19 percent absence rates among teachers is high in countries which are not developed than the teachers in the developed countries. (Rogers et al, 2006). Size of schools is normally small in the ruler areas of developing countries and majority of these remain closed due to absenteeism of teachers. Teachers in government schools take more leaves than teachers in private schools. Majority, the reasons mentioned for their leaves are limited availability of transports to that area or some other important work. Teacher's presence, their number and dedication effect number of students as well. (Ameeq et al, 2018) .The National policy on Education (2004) recommended that the teacherstudents' ratio should be 1:30. At that time, in Pakistan the no of students per teacher was 39. In 2000, the minimum number of students to one teacher was 33 and in 2016 it became maximum 47 numbers of students to one teacher. It is generally considered better to have fewer pupils per teacher. (Cooper, 2010).

From annual statistical report of government schools (kpk) of different previous year's number of teachers observed was less. Rude and poor behavior of government teachers also affects the presence and enrollment of students. (Ashfaq, 2018). Female teachers were given lesser chance compared to male teachers. Country's progress and development requires equal opportunities to both genders. Student enrollment and their learning outcomes are positively related to presence and attendance of teachers. (Mosufer, 2011).

\section{Analysis}

The provincial government of KPK publishes an annual statistical report of government schools. A total of 6319 girl's secondary schools are included in this research work and consider KPK schools statistical reports for year 2009-2015. Further the comparison of two government's (girl's secondary 
schools) education policies is made, in which we compare three variables i.e. No. of teachers, no of institutions and basic facilities, which effect student enrollment.

To study the relationship between student enrollment and the other variables, secondary data was gathered about girl's government secondary schools in KPK. The resulting data contains information on student enrollment, number of teachers, number of institutions and basic facilities (like boundary walls, electricity, water facilities, number of classrooms, computer and lab facilities etc.). This research uses KPK girl's government secondary schools statistical data for 2009, 2010, 2011, 2012, 2013, 2014 and 2015. The dependent variable is student enrollment. Number of teachers, number of institutions and basic facilities are taken as independent variables. The schools without basic facilities are not included in the data.

The results from comparing the data of last three years (2009-2012) of previous government with first three years (2013-2015) of present government have shown an increasing trend in student enrollment, no of teachers, no of institutions and basic facilities. This increase in all these variables shows improvement in the quality of studies which leads to increasing interest of students. In order to achieve high student enrollment the above mentioned variables play an important role. From the comparison between two governments it is clear that the changes made in educational policy by the present government has increased student enrollment. For this purpose the secondary data is collected from the Annual Statistical Report of government schools from the year 2009-2015. By using linear and multiple regression technique, find out the relationship between student enrollment and other variables

Table: 1 Comparison Table

\begin{tabular}{|l|l|l|l|}
\hline \multicolumn{5}{|l|}{ COMPARISON BETWEEN THE TWO GOVERNMENTS } \\
\hline & \multicolumn{1}{|l|}{} & \\
\hline & $\begin{array}{l}\text { Previous Government } \\
(2009-12)\end{array}$ & $\begin{array}{l}\text { Current Government } \\
(2012-15)\end{array}$ & $\begin{array}{l}\% \text { Change/ } \\
\text { Improvement }\end{array}$ \\
\hline $\begin{array}{l}\text { Student } \\
\text { Enrollment }\end{array}$ & 231678 & 254758 & $9.96 \%$ \\
\hline No. of teachers & 16246 & 16947 & $4.32 \%$ \\
\hline Basic Facilities & 3030 & 3234 & $6.73 \%$ \\
\hline $\begin{array}{l}\text { No. } \\
\text { institutions }\end{array}$ & 3030 & 3289 & $8.54 \%$ \\
\hline & & & $29.55 \%$ \\
\hline Total & 253984 & 278228 & \\
\hline
\end{tabular}

The comparison between two governments indicates a $29 \%$ improvement due to the reforms brought by the present government. From the table, it is clear that the student enrollment in previous government was 231,678 while in current government it is increased to 254,758 . The number of teachers in previous government was 16,246 while in current government it is increased to 16,947. The number of institutions in previous government was 3,030 while in present government it is increased to 3,289 . Basic facilities in previous government were 3,030 while in current government it is increased 
to 3,234 . This $29 \%$ improvement shows that the current government is making new policies to bring a change in education system and to improve the quality of studies.

Table: 2

\begin{tabular}{|l|l|l|l|l|}
\hline YEAR & $\begin{array}{l}\text { Student } \\
\text { Enrollment }\end{array}$ & $\begin{array}{l}\text { No. } \\
\text { Teachers }\end{array}$ & $\begin{array}{l}\text { Basic } \\
\text { Facilities }\end{array}$ & $\begin{array}{l}\text { No. } \\
\text { Institutions }\end{array}$ \\
\hline $\mathbf{2 0 0 4 - 2 0 0 5}$ & 68518 & 4838 & 909 & 909 \\
\hline $\mathbf{2 0 0 5 - 2 0 0 6}$ & 74714 & 5120 & 920 & 920 \\
\hline $\mathbf{2 0 0 6 - 2 0 0 7}$ & 69961 & 4868 & 929 & 929 \\
\hline $\mathbf{2 0 0 7 - 2 0 0 8}$ & 69033 & 5352 & 978 & 978 \\
\hline $\mathbf{2 0 0 8 - 2 0 0 9}$ & 70217 & 5268 & 987 & 987 \\
\hline $\mathbf{2 0 0 9 - 2 0 1 0}$ & 71207 & 5359 & 994 & 994 \\
\hline $\mathbf{2 0 1 0 - 2 0 1 1}$ & 77449 & 5458 & 1013 & 1013 \\
\hline $\mathbf{2 0 1 1 - 2 0 1 2}$ & 83022 & 5429 & 1023 & 1023 \\
\hline $\mathbf{2 0 1 2 - 2 0 1 3}$ & 83963 & 5534 & 1049 & 1086 \\
\hline $\mathbf{2 0 1 3 - 2 0 1 4}$ & 87852 & 5383 & 1072 & 1090 \\
\hline $\mathbf{2 0 1 4 - 2 0 1 5}$ & 82943 & 6030 & 1076 & 1113 \\
\hline $\mathbf{2 0 1 5}-2016$ & 78799 & 6032 & 1088 & 1126 \\
\hline $\mathbf{2 0 1 7 - 2 0 1 8}$ & 321190 & 6260 & 1147 & 1198 \\
\hline Total & 565235 & $\mathbf{3 9 2 2 5}$ & $\mathbf{6 2 2 7}$ & $\mathbf{6 3 1 9}$ \\
\hline & & & & \\
\hline
\end{tabular}

This table shows student enrollment, number of teachers, number of institutions and basic facilities from the year 2004-2018. The table includes a total of 13 observations, which contains data on girl's government secondary schools of KPK only. Total number of institutions is 6319, in which 6227 schools are with basic facilities, and a total of 565235 students are enrolled in these institutions. The total number of teachers is 39225. We used regression to find the relationship between dependent and independent variables. Student enrollment is taken as dependent variable in all the regression analyses. We first attempt to find out the linear regression of student enrollment (dependent variable) with each of the independent variable. And then the multiple regression technique is used for dependent variable and all the independent variable. The result of linear regression is significant for all variables. While the result of multiple regression is insignificant, which shows that the change in dependent variable i.e. student enrollment is not only due to these three variables. But there are some other factors (variables) which also affect the student enrollment.

\section{Statement of Hypothesis}

For a better understanding of the effect of the number of institutions, number of teachers and basic facilities on the student enrollment, the following hypotheses are framed.

- Hypothesis 1 (Ho): There is no relationship between number of institutions and students enrollment. $¥ 0$

- Hypothesis (H1): There is a significant relation between number of institutions and student enrollment. $\nRightarrow \mathrm{O}$

- Hypothesis 2 (Ho): There is no relationship between number of teachers and student enrollment. $\nRightarrow 0$

- Hypothesis (H1): There is a significant relation between number of teachers and student enrollment. $\$ 0$ 
- Hypothesis 3 (Ho): There is no relationship between basic facilities and student enrollment. $\neq 0$

- Hypothesis (H1): There is a significant relation between basic facilities and student enrollment. HOO

\subsection{Interpretation of Results}

Table: 3

\begin{tabular}{|l|l|l|l|}
\hline Variables & Coefficients & t-stat & P-value \\
\hline Intercept & -261341.253 & -0.571034606 & 0.581952314 \\
\hline No. of Institutions & 488.8334289 & 2.726545244 & 0.0197 \\
\hline No. of Teachers & 96.17795866 & 2.527720934 & 0.02808707 \\
\hline Basic Facilities & 590.6239525 & 2.61098729 & 0.024214829 \\
\hline
\end{tabular}

This table shows the regression analysis. From this we can examine the relationship between the dependent and independent variable. First of all we will interpret all the variables to check their influence on dependent variable.

\subsubsection{Interpretation of Intercept $(\alpha)$}

Alpha $(\alpha)$ it is also called as intercept. It shows the number of student enrolled independent of all the

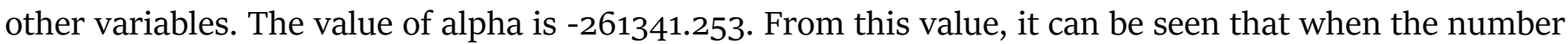
of institutions, number of teachers and basic facilities are equal to zero, then the student enrollment will decrease by -261341.253 .

\subsubsection{Interpretation of $\boldsymbol{\beta} \mathbf{1}$ (Number of Institutions)}

- Student's enrollment will increase by 488.833 when the number of institutions increases by 1.

- There is a direct relation between the number of institutions (X1) and student's enrollment (Y).

\subsubsection{INTERPRETATION OF B2 (Number of Teachers)}

- Student's enrollment will increase by 96.177 when the number of institutions increases by 1 .

- There is a positive (direct) relationship between number of teachers (X2) and student's enrollment (Y).

\subsubsection{INTERPRETATION OF B3 (Basic Facilities)}

- Student's enrollment will increase by 590.6239525 when basic facilities increase by 1.

- There is a direct (positive) relation between basic facilities (X3) and number of institutions (Y).

\subsection{T-STATISTICS}

The t-statistic is used in a t-test when you are deciding if you should support or reject the null hypothesis. Here, all the variables are significant at $10 \% \& 5 \%$. So, we are able to reject the null hypothesis at $10 \%$ \& $5 \%$.

- T-stat for number of institutions is 2.72 which are significant at $10 \%$ and $5 \%$. So, we are able to reject the null hypothesis at $5 \%$ and $10 \%$.

- T-stat for number of teachers is 2.52 which are significant at $10 \%$ and $5 \%$. So, we are able to reject the null hypothesis at $5 \%$ and $10 \%$. 
- T-stat for basic facilities is 2.61 which is greater than 1.645 (10\%) and 1.9645 (5\%). So, it is significant at $10 \%, 5 \%$. So, we are able to reject the null hypothesis.

- P-VALUE

P-value is used to check the significance level. It is defined as the probability of occurrence of a given event.

- P-value for number of institutions is 0.019 which is significant at $5 \%$ and $10 \%$. So, we are able to reject the null hypothesis at $5 \%$ and $10 \%$.

- P-value for number of teachers is 0.028 which is significant at $5 \%$ and $10 \%$. So, we are able to reject the null hypothesis at $5 \%$ and $10 \%$.

- P-value for basic facilities is 0.024 which is less than $0.05(5 \%)$ and 0.10 (10\%). So, it is significant at $5 \%$ and $10 \%$. So, we are able to reject the null hypothesis.

\subsection{R-SQUARE}

It is used to measure the reliability of the regression model.

- In linear regression, the value of $r$-square for the number of institutions is 0.40 . It means that $40 \%$ variation in dependent variable (student enrollment) is due to the independent variable (number of institutions). The value of r-square for number of teachers is 0.36 . It shows that $36 \%$ variation is due to the number of teachers (independent variable). The value of r-square for basic facilities is 0.38 , which shows that $38 \%$ variation in student enrollment (dependent variable) is due to basic facilities (independent variable).

- The value of r-square for the model (which consists of dependent variable and all the three independent variables) is 0.41 . It means that $41 \%$ variation in the dependent variable (student enrollment) is due to the independent variables (i.e. number of institutions, number of teachers and basic facilities). It also shows that there are some other factors (variables) which also affect student enrollment.

\section{FINDINGS \& RECOMMENDATIONS}

This research explains the relationship between student enrollment and number of institutions, number of teachers and basic facilities for girl's government secondary schools in KPK, Pakistan. In line with my hypothesis, we found evidence of a direct, positive and statistically significant relationship between the dependent variable and all the three independent variables. UNESCO figures, reveals a great difference between the girls and boys enrollment in Pakistan, with boys having more enrollment than girls. (Dawn, 23 Feb 2004, editorial)

We found a positive and statistically significant relationship between student's enrollment and number of institutions. These findings are consistent with the hypothesis because with the increase in number of institutions, student's enrollment also increases.

The relationship between number of teachers and student's enrollment is also consistent with the hypothesis. It is also consistent with that of (Mosufer, 2011), who find that student enrollment and their learning outcomes are positively related to presence and attendance of teachers.

The findings are also consistent with the hypothesis that the provision of basic facilities increases student's enrollment. Our findings are consistent with those of Hayat (2017), who find that the availability of basic facilities is positively and significantly associated with enrollment. This relationship is stronger for schools in rural areas, for female-only schools and for secondary schools. 
There are also certain limitations to the study. There are only three independent variables are included in this study. But the fact is that there are some other factors which also affect student enrollment (dependent variable). The smaller $r$-square also shows that the variation in dependent variable is not only due to these three variables. The economic and financial conditions also affect student's enrollment. If the economic conditions are good, then it will have a positive impact on student's enrollment. The study only focuses on the girl's government secondary schools of KPK, which covers only a small part of the population of Pakistan. A nation-wide study would be more beneficial.

\section{CONCLUSION}

The purpose of this study is to compare the educational performance resulting from the educational policies and their reforms of previous government (elected in 2008) and current government (elected in 2013) in KPK. Specifically girl's government schools of middle level are viewed. Student enrolment, number of teachers, basic facilities in schools and number of institutions/schools are considered as the most promising improvement variables for public sector education system in KPK and overall Pakistan.

The results from comparing the data of last three years (2009-2012) of previous government with first three years (2013-2015) of present government have shown an increasing trend in all the variables. From this comparison we infer that the changes made in educational policy by the present government has increased student enrollment and improved the quality of studies.

This conclusion is based on a sample of middle level girl's government schools of KPK which covers only a small part of the population of Pakistan. Also, we acknowledge some limitations to the study by including only three independent variables in this study and ignoring other (economical and financial conditions) which may affect student enrollment (dependent variable). Therefore, a nationwide comprehensive study regarding this matter would be suggested.

\section{Refrences}

Ameeq, M., Muneeb, M. H., Jabeen, M., \& Fatima, L. (2018) Impact of Teacher Absenteeism on Student Achievement: A Case of South Punjab District Muzaffargarh, Pakistan. Journal of Education and Practice.

Ashfaq, M. (2017, December 11). 1000 primary school shut down in KP over low enrolment. Dawn. Ashfaq, M. (2018, March 21). 51 percent Khyber Pakhtunkhwa girls don't go to school: report. Dawn.

Bourdieu P., Passeron J.-C. (1977). Reproduction in Education, Culture and Society. London: Sage Publications.

Bowen W. G., Kurzweil M. A., Tobin E. M., Pichler S. C. (2005). Equity and Excellence in American Higher Education. Charlottesville, VA: University of Virginia Press.

Chaudhury, N., Hammer, J., Kremer, M., Muralidharan , K., \& Halsey , R.F. (2006). “ Missing in Action: Teacher and Health Worker Absence in Developing Countries". Journal of Economic Perspectives, 20, 91-116.

Cooper, H. M. (1989). Does a reducing student-to-teacher ratio affect achievement? Educational Psychologist, 24(1), 79-98.

Did the PTI deliver on its promise to revamp education in KP (2018, April 19), Daily Times.

Dildar, M. S., Saif, N. N., \& Naz, A. (2016, January 5). Review of Educational Policies of Pakistan: Planning and Implication flows. Retrieved from https://www.researchgate.net/publication/319622700_Review_of_Educational_Policies_of_Pakistan_Plan ning_and_Implication_flows

Duru-Bellat M. (2008). Recent trends in social reproduction in France: should the political promises of 
education be revisited? Journal of Education Policy,23(1), 81-95.

Fayyaz. (2011). Impact of Teacher Quality on the Academic Achievement of Students at Secondary Stage in Punjab (Pakistan). European Journal of Social Sciences, 19(1), 106-113.

Forquin J. C. (1992). École et Culture: Le Point de Vdes Sociologues Britanniques. Bruxelle: De Boeck.

Glewwe, P. W., E. A. Hanushek, S. D. Humpage, and R. Ravina. (2011). "School Resources and Educational Outcomes in Developing Countries: A Review of the Literature from 1990 to2010."In Education Policy in Developing Countries, edited by P. W. Glewwe. Chicago: University of Chicago Press.

Glewwe, P., \& Kremer, M. (2005). Schools, teachers, and education outcomes in developing countries, in: Handbook on the Economics of Education.

Goldhaber, D. D., \& Brewer, D. J. (1997). 'Why don't schools and teachers seem to matter? 'Assessing the impact of unobservable on educational productivity '. Journal of Human Resources . 32, 505-523.

Gormley, W. T. (1987). Institutional Policy Analysis: A Critical Review. Journal of Policy Analysis and Management, 6(2), 153.

Hanushek, E. A. (1986). The Economics of Schooling: Production and Efficiency in Public Schools. Journal of Economic Literature. 24, 1141-1171.

Hayat, F. A. (2017). The Relationship between Access to Toilets and School Enrollment in Pakistan (Unpublished master's thesis).Georgetown University, Washington D.C, U.S.A.

Herz, B. K., \& Sperling, G. B. (2004). What works in girls education: Evidence and policies from the developing world. New York: Council on Foreign Relations.

http://www.economics.harvard.edu/faculty/kremer/ papers/EconEducationHandbook.pdf

Maguire, M., Ball, S. J., \& Braun, A. (2012). How schools do policy: Policy enactments in secondary schools. London: Routledge.

Mahfooz, S. (2018, May 7). Education row in KPK. Pakistan Today.

Memon,G.R. (2007). Education in Pakistan: The key Issues, problems and the new challenges. Journal of Management and Social Sciences, 3(1), 72-85.

Musofer, M. A. (2011, Feb 05). Why gender matters in education. Dawn.

Neilson, C., \& Zimmerman, S. (2011). "The Effect of School Construction on Test Scores, School Enrollment, and Home Prices”. IZA Discussion Paper.

Pakistan student-teacher ratio, retrieved https://www.theglobaleconomy.com/Pakistan/Student_teacher_ratio_primary_school/

Parsons T. (1959). The School Class as a Social System: Some of its Functions in American Society.Cambridge, MA: Harvard Educational Review.

Rehan, S. (2012, March 20). Poor condition of public school. Pakistan Today.

Shah, S. F., Khan, I. U., Khan, D., \& Khan, M. F. (2013). "The Impact of Physical Facilities on Quality of Primary Education in Khyber Pakhtunkhwa as Perceived by Teachers". IOSR Journal of Humanities and Social Science., 18(3 (Nov -Dec. 2013)).

Shall I Feed My Daughter, or Educate Her? : Barriers to Girls' Education in Pakistan. (2018, November 13). Retrieved from: https://www.hrw.org/report/2018/11/12/shall-i-feed-my-daughter-oreducate-her/barriers-girls-education-pakistan

Yosso T. J. (2002). Toward a critical race curriculum. Equity \& Excellence in Education, 35, 93-107. 